\title{
RELIGIÁO, VIDA E SOCIEDADE: BREVE ESTUDO A PARTIR DE Bergson e Freud
}

\author{
Geovana da Paz Monteiro ${ }^{1}$
}

\begin{abstract}
Resumo: $\mathrm{O}$ artigo visa a indagar em que medida a religiosidade, observada a partir de seu contexto originário, seria um dos meios encontrados pela civilização para abafar impulsos humanos primários tendentes à desagregaçáo social e moral. A despeito dessa tentativa de controle, questiona-se o quanto tais impulsos ditos primitivos prevalecem em nossa constituição biológica, psíquica e social, de modo a justificarem comportamentos aberrantes táo comuns em nossa época. Tomam-se por base as ideias de Henri Bergson, presentes no segundo capítulo d'As duas fontes da moral e da religiäo, intitulado "A religiāo estática”, em cotejo aos argumentos de Sigmund Freud, apresentados, sobretudo, em O futuro de uma ilusão e Totem e tabu. Apesar da aproximação com as ciências sociais, segue-se a hipótese de que o livro de Bergson nutre um diálogo mais fecundo com a teoria freudiana, no que tange à compreensão da religiosidade dita primitiva em oposição, ou não, à civilizada.
\end{abstract}

Palavras-chave: Bergson. Freud. Religião. Moral. Vida. Sociedade.

\section{INTRODUÇÃo}

Como peculiar ao discurso filosófico, as ideias de Henri Bergson e Sigmund Freud, embora elaboradas entre séculos anteriores (XIX e XX), podem muito bem iluminar a compreensão do nosso tempo concreto. $\mathrm{O}$ período que atualmente atravessamos prefigura um desafio à humanidade, à ciência, à filosofia, mas também à religião. Assim, de modo peculiar, esses dois grandes pensadores nos ajudam a compreender as origens do fenômeno religioso, seu desenvolvimento e atuação como ferramenta de contenção dos

${ }_{1}^{1}$ Doutora em Filosofia. Professora Adjunta de Filosofia da Universidade Federal do Recôncavo da Bahia (UFRB), Amargosa, BA - Brasil. (D) https://orcid.org/0000-0002-7404-9312. E-mail: geovana@ufrb.edu.br.

https://doi.org/10.1590/0101-3173.2021.v44n3.14.p151

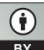

This is an open-access article distributed under the terms of the Creative Commons Attribution License. 
impulsos humanos antissociais contrários à vida, os quais precisamos abrandar, caso estejamos dispostos à colaboração social.

A convergência entre o pensamento de Bergson e Freud tem sido amplamente abordada por seus intérpretes, principalmente no que concerne às questóes relacionadas à memória e ao inconsciente. Porém, sobre a relação entre o que pensaram a respeito da religião, ainda é tema pouco explorado. ${ }^{2}$ Dessa forma, nosso breve estudo visa a destacar que a obra de 1932, As duas fontes da moral e da religião, ${ }^{3}$ muitas vezes associada a reflexóes de cunho sociológico, ${ }^{4}$ ou interpretada como corolário das teses outrora apresentadas por Bergson, em $A$ evolução criadora, ${ }^{5}$ nutre de maneira muito fecunda uma relação com a análise freudiana da civilização. Entendemos que a aproximação entre os dois autores poderia iluminar a compreensão da contemporaneidade, com base no tema específico da religiāo, sua influência em nosso modo de vida, suas contradições e seus limites. É alguma coisa sobre a qual ambos souberam refletir profundamente e cujas ideias, pretendemos mostrar, se revigoram em nosso tempo.

Partindo desse preâmbulo, inspirados pelo Bergson d'As duas fontes (2005) e pelo Freud de Totem e tabu (1913/2015) e de O futuro de uma ilusão (1927/2014), ${ }^{6}$ indagamos primeiramente: enquanto indivíduos ditos civilizados, por que mantemos superstiçóes completamente absurdas e em

2 A coletânea organizada por Brigitte Sitbon (2014), Bergson et Freud, elenca uma série de artigos que reforçam a correspondência entre os dois autores. Assim, também, uma rápida pesquisa poderia indicar uma gama de trabalhos acadêmicos sobre a aproximação entre as ideias de Freud e Bergson, no campo da memória e do inconsciente. Por outro lado, são escassas as referências que os aproximam no estudo da religiáo. Entre tais, podemos citar o excelente artigo de Vincent Delacroix, La religion comme répétition. Bergson à la lumière de Freud, com importantes contribuiçôes sobre o tema.

${ }^{3}$ Em alguns momentos, nós nos referiremos a essa obra simplesmente como As duas fontes.

${ }^{4}$ As duas fontes seria exatamente, segundo Delitz (2012), uma explicação das formas elementares da vida social amparada no vital. Seria, portanto, uma resposta de Bergson às reaçóes durkheimianas ao seu pensamento. De acordo com Delitz (2012), embora a influência do pensamento bergsoniano no campo das ciências sociais, no início do século XX, tenha sido profunda, a partir da década de 30, viu-se também uma espécie de marginalização dessas ideias, sob a acusação de irracionalismo. Para a sociologia, “[...] se opor ao 'bergsonismo' era se opor ao 'misticismo', à antimodernidade e ao antintelectualismo." (DELITZ, 2012, p. 43, traduçáo livre). Assim, por uma leitura equivocada ou superficial, a escola de Durkheim encontrava na filosofia da duraçáo seu perfeito antagonista e, de certa forma, as teses de Bergson teriam servido de impulso para Durkheim ser Durkheim. Sobre a relaçáo entre As duas fontes e as ciências sociais, vale conferir também Caeymaex (2017), Sitbon-Peillon (2009) e Pinto (2016).

5 Tese defendida por Worms (2014), em Bergson ou les deux sens de la vie.

${ }^{6}$ Para as obras de Freud, optamos por citar primeiramente a data de sua publicação original e, em seguida, a data da publicação da traduçấo que ora utilizamos. 
nome delas cometemos os piores crimes? Como é possível que, em nome de uma religião ou interesses econômicos, açôes violentas sejam orquestradas e vidas cruelmente ceifadas diariamente, em todo o mundo? Como explicar a ascensão da ideologia fascista em pleno século XXI, após a história ternos mostrado do que o fascismo foi capaz, no século XX? A resposta para esses questionamentos e outros relacionados náo é simples, envolvendo a análise de uma série de fatores históricos, políticos e econômicos, os quais não poderíamos compilar no escopo de um artigo. No entanto, a partir de um olhar filosófico específico, almejamos traçar uma via de reflexão sobre as contradiçóes da inteligência, as quais deram origem à religião instituída e à moral que culminaram na situação presente.

Embora o projeto bergsoniano de compreensão da sociedade, bem como da religiosidade e moral nascentes, abra caminho para o filósofo pensar a possibilidade de uma intuição alargada da vida, através da experiência mística, nosso objetivo aqui não será aprofundar a discussão sobre tal experiência. Pretendemos antes compreender como se dá o nascimento e posterior desenvolvimento de uma religiosidade natural, conformada aos interesses de autopreservação da espécie. Nessa medida é que se torna possível o diálogo com a abordagem freudiana. Porém, a fim de compreendermos o estofo conceitual d'As duas fontes, virá a nosso auxílio uma rápida digressão ao evolucionismo de Bergson, apresentado vinte e cinco anos antes, n'A evolução criadora. Esse retorno é fundamental, porque contextualiza a discussão da obra de 1932, quando esta atribui, tanto à sociedade quanto à religiáo, um caráter natural, uma marca evolutiva da espécie.

\section{A EVOLUÇã́o da VIDA}

No âmbito de uma filosofia que restitui ao tempo sua duração enquanto jorro de novidade ou fluxo criativo, a leitura d'As duas fontes deixanos perceber uma correlação estabelecida entre o vital, compreendido em função da evolução de tendências divergentes no fluxo temporal, e o social, desdobramento específico de uma tendência instintiva à autopreservação. Retomando as teses outrora desenvolvidas na obra A evolução criadora (2005a), Bergson estará em condições então de completar sua investigação sobre a vida, integrando agora ao vital os aspectos sociais e religiosos.

O filósofo partiu do pressuposto de que, enquanto teorias científicas, todas as perspectivas evolucionistas existentes à época se confirmavam como 
interpretaçôes parciais, pois, ao investigarem a organização da vida como um objeto fabricado, não davam conta, a seu ver, do essencial, a saber, o fluxo criativo, espiritual, que anima a matéria, já que Bergson (2005a) entende a vida em geral como a evolução de um impulso que progride ao modo de uma consciência, porque preserva em cada uma de suas tendências resquícios da impulsão primeira. Esse denominado elã vital constitui a energia espiritual que se desenvolveu em distintas direçóes, em movimento criativo e contínuo, contornando a resistência da matéria bruta.

A materialidade é concebida, em $A$ evolução criadora, como algo que encaminha tudo o que existe para sua degradação, ao contrário do espírito, que é potência criativa, mudança, transformação. Dada essa dualidade fundamental entre materialidade e espiritualidade, a evolução da vida se forjará a partir de um misto, como fica explícito no texto bergsoniano:

Decerto, a vida que evolui na superfície de nosso planeta está vinculada à matéria. Caso fosse pura consciência, com mais razão ainda supraconsciência, seria pura atividade criadora. $\mathrm{Na}$ verdade, está cravada em um organismo que a submete às leis gerais da matéria inerte. Mas tudo se passa como se fizesse todo o possível para libertar-se dessas leis. (BERGSON, 2005a, p. 267).

Essa tentativa de libertar-se da matéria pelo vivo se impôs, segundo Bergson (2005a), através de tendências, das quais instinto e inteligência se destacaram no mundo animal. Instinto e inteligência representam, assim, a vitória da vida sobre a matéria inerte. A tendência animal, cindindo-se em vias opostas, desenvolveu nos humanos uma consciência desperta, ativa e, em seu traço mais marcante, pragmática. Os seres conscientemente ativos souberam se utilizar da inteligência para dominar a matéria. Todavia, ao passo que a racionalidade aflorou, com toda sua potência fabricadora e inventiva, a

\footnotetext{
$7 \mathrm{O}$ elã vital constitui o ponto central da argumentação desenvolvida em $A$ evolução criadora, pois ilustra, como expressou Worms (2000), a ideia da vida como ato único que tende a se individualizar por um processo múltiplo, na duração. Todavia, a unidade profunda desse impulso criativo seria apreendida apenas por intuiçãa. Sendo a intuição um ato simples, ela denota uma experiência imediata e, em sentido místico, é a intuição do próprio elá vital compreendido como Deus. Em 1907, Bergson (2005a, p. 270) identifica explicitamente o elã vital a Deus, quando afirma: "Se, por toda parte, é a mesma espécie de ação que se realiza, quer se desfaça, quer procure refazer-se, simplesmente exprimo essa similitude provável quando falo de um centro de onde os mundos jorrariam como foguetes de um imenso buquê - com a condiçấo, todavia, de que eu não tome esse centro por uma coisa, mas por uma continuidade de jorro. Deus, assim definido, nada tem de já pronto; é vida incessante, ação, liberdade."
} 
tendência animal oposta, o instinto, se esmaeceu, restringindo-se quase por completo aos animais não humanos.

Considerando a presença mínima de inteligência em outros animais, assim como a do instinto no humano, bem se vê que é apenas neste último no qual a faculdade intelectual encontra seu máximo potencial de desenvolvimento. Todavia, embora a inteligência seja uma faculdade de ação - em seu amplo poder de dar forma e usos à matéria bruta, de criar instituiçôes e normas sociais -, ela se desdobra também em representação. A capacidade de representar póe os seres humanos diante de uma série de questionamentos e especulaçóes, entre os quais encontrará a consciência de sua pequenez no Universo e de sua própria finitude, o que muitas vezes poderá pôr em risco o equilíbrio natural. Um antídoto contra esse poder dissolvente da inteligência deverá ser providencialmente forjado pela natureza: a religião. A fim de adentrarmos em definitivo o tema da religião nascente, abordaremos sucintamente a relação entre o vital e o social, tal como entenderá Bergson, no primeiro capítulo d'As duas fontes.

\section{Do vital Ao SOCIAL}

Em 1932, n'As duas fontes da moral e da religiäo, prolongando a discussão iniciada n'A evolução criadora, Bergson estende ao domínio social as conclusōes de seu evolucionismo, porque observa que a sociabilidade é também inerente ao reino animal. Para ele, enfim, "[...] o social está no fundo do vital” (BERGSON, 2005, p. 108), seja em organismos simples, seja nos mais complexos. O filósofo conferirá então à sociedade uma organicidade própria que imita, no plano contingente das relaçóes humanas, a necessidade inerente às organizaçôes naturais. Sendo composta por indivíduos conscientes de sua liberdade, sua sustentação virá do cultivo de hábitos de comando e hábitos de obediência. A força do hábito contribuirá para garantir a coesão do "organismo" e seu perfeito funcionamento, visto que hábitos internalizados podem exercer grande pressão sobre a vontade.

O "eu social" submetido ao padrão imposto corresponderá a uma camada superficial da subjetividade. Como ressalta Bergson (2005, p. 27), “[...] cada um de nós pertence à sociedade, tanto quanto a si mesmo." Assim, para além da originalidade profunda e inefável que distingue cada indivíduo enquanto duração psicológica, a obrigação nos liga aos outros e a nós mesmos, mas, ao custo de muitas renúncias, das quais será colhido o equilíbrio social. 
O "eu social" será parte fundamental da existência humana, pois a obrigação para com o outro terminará por ser uma obrigação para consigo mesmo. Para fins de conservação, portanto, a sociedade forjará intermédios entre ela e o indivíduo, tais como a família, o trabalho, a religião. Em cada um desses grupos, mantemos obrigaçóes e nos sentimos integrados, socializados. Tornase cômodo obedecer, seguir a trilha que a sociedade fechada traçou para nós. Logo, abandonamos obedientemente nossa existência à vida social, sufocando, muitas vezes, interesses profundos em nome da coletividade (BERGSON, 2005).

Precisamos notar, entretanto, que Bergson (2005) interpreta a obrigação moral de modo peculiar. Embora se reforce pelo hábito, para o filósofo, o ato de obedecer, de se submeter às exigências sociais, teria um fundamento natural, evolutivo. Tratar-se-ia de um resquício da tendência à autopreservação, uma tendência instintiva à conservação da vida. Em suma, ainda que sejamos seres definidos fundamentalmente pela inteligência, há em nós, humanos, uma espécie de "instinto virtual”, decorrente do processo evolutivo, o qual nos impele à autoconservação. Daí que, não obstante a liberdade que acompanha nossa consciência desperta possa nos enveredar para um pensamento individualista, no fundo de nós residiria também uma tendência natural à sociabilidade, à coletividade.

Por conseguinte, a chave para a compreensão do fechamento orgânico de nossas condutas sociais, morais e religiosas se encontraria nesse caráter vital da obrigação. Obedecemos para nos conservarmos enquanto espécie. $\mathrm{E}$, por sermos animais, constituímos uma parte do mundo natural, embora esqueçamos deliberadamente esse fato inquestionável. De forma semelhante a outros animais, necessitamos nos agrupar, a fim de provermos nossa subsistência, o que fica claro na seguinte passagem d'As duas fontes:

[...] seja qual for a filosofia a que nos liguemos, somos forçados a reconhecer que o homem é um ser vivo, que a evolução da vida, nas suas duas linhas principais, se cumpriu na direção da vida social, que a associação é a forma mais geral da atividade viva uma vez que a vida é organização [...] (BERGSON, 2005, p. 89).

A partir dessa estrutura complexa que nos compóe enquanto vivos, dessa mistura entre consciência, vida e sociabilidade, Bergson encontrará uma via de interpretação para as ambiguidades do comportamento humano. Como veremos, a religiáo cumpre um papel crucial na manutenção da vida, mas, 
de maneira paradoxal, pode também interferir negativamente no processo civilizatório. Então, dado que o fenômeno religioso seja múltiplo e complexo, só seria possível tratá-lo em profundidade atentando-nos para os diversos níveis da vida, implicados intimamente uns nos outros. Veremos também que as ideias de Sigmund Freud entram em sintonia com o pensamento bergsoniano, enriquecendo a interpretação da religião nascente e suas consequências gerais para a vida humana em sociedade.

\section{Do PRIMITIVO AO CIVILIZADO: O PESO DA SOCIEDADE}

Sigmund Freud argumenta, em seus textos culturais, que, embora a civilização se realize como amadurecimento da condição humana meramente animal, as renúncias necessárias à sua manutenção são absorvidas sempre como um fardo pesado demais. Assim, "tendências destrutivas" (FREUD, 1927/2014, p. 235) se constatam nos seres humanos, contra as quais a civilização deverá encontrar mecanismos de defesa. A religiosidade é um desses mecanismos, mas, para compreendê-la de fato, seria preciso acessar primordialmente a vida interior profunda, suas tendências e impulsos. Tentaremos mostrar, então, que a posiçáo de Bergson se aproxima da visão de Freud, na medida em que ambos adotam um ponto de vista misto, no estudo da religião, juntando o social, naturalizado n'As duas fontes, e o psicológico, remetendo ao que vamos denominar aqui por "primitivo" (SITBON-PEILLON, 2009, p. 244).

No segundo capítulo d'As duas fontes, intitulado "A religião estática", Bergson constata o show de horrores que foram e ainda são as religiōes e, diante disso, chega ao ponto de questionar a real capacidade humana para o raciocínio. É a percepção de um filósofo em plena década de 30 do século $\mathrm{XX}$, todavia, sua constatação bem poderia se aplicar aos dias atuais. A mesma perplexidade encontramos em Freud (1927/2014, p. 234), ao afirmar que, "[...] enquanto a humanidade fez contínuos avanços no controle da natureza, podendo esperar avanços ainda maiores, não se constata seguramente um progresso igual na regulação dos assuntos humanos." Tais assuntos, quase sempre, obedecem a uma visão religiosa de mundo. Indagamos aqui, portanto, pelo olhar da filosofia e da psicanálise: por que mantemos ainda hoje crenças e práticas tidas por não civilizadas, muitas vezes absurdas, considerando os progressos atingidos pela inteligência?

Filósofos, sociólogos, antropólogos e psicólogos estão cientes de que apenas o estudo da vida humana, em seu estágio mais natural, poderá nos dar 
resposta plausível para essa questão (SITBON-PEILLON, 2009). Contudo, para entendermos o caminho seguido por Bergson (2005), precisamos ter clara sua recusa a tratar a vida civilizada como um estágio evoluído do primitivo. ${ }^{8}$ Para o filósofo francês, a distinção entre a "mentalidade primitiva" e a "civilizada" não é de ordem ontológica. O civilizado difere do primitivo somente na medida em que adquiriu ganhos culturais os quais se cristalizaram na linguagem, na ciência, na filosofia, na arte e na religião.

Freud, por outro lado, em diversas fases de sua obra, deixa implícita a defesa da tese filogenética, no que concerne à transmissão cultural. Segundo Winograd (2007, p. 79), "[...] para Freud, a filogênese anímica e a filogênese biológica trabalham juntas no que ele chama de fatores constitucionais." $\mathrm{Ou}$ seja, caracteres culturais seriam transmitidos hereditariamente no processo evolutivo, donde a noçáo de que o homem primitivo configure um estágio anterior ao civilizado: "[...] assim consideramos os que são chamados de selvagens e semisselvagens, cuja vida psíquica tem especial interesse para nós, se nela pudermos reconhecer um estágio anterior e bem conservado de nossa própria evolução." (FREUD, 1913/2015, p. 18). ${ }^{9}$

Valerá, entretanto, atentarmos para um ponto essencial sobre o qual Bergson e Freud parecem concordar: da perspectiva do sujeito, primitivo é seu estado interior profundo, inconsciente e, se preferirmos, infantil. Apuremos o olhar para esse conteúdo que nos constitui enquanto duração, fazendose presente em cada atitude que tomamos ou deixamos de tomar, na vida cotidiana.

\subsection{As PULSÓES E AS TENDÊNCIAS VITAIS}

Segundo Freud (1915/2013), há em todos nós tendências arcaicas as quais, inconscientemente, comandam nossas açôes. São as chamadas pulsóes (Triebe) ou instintos. O autor discorreu sobre elas em diversas fases de sua

\footnotetext{
8 Posiçáo que explicita n'As duas fontes, quando discorda das teses do sociólogo francês Lucien LévyBrühl (1857-1939). Segundo Sitbon-Peillon (2009), Brühl mudará de opinião mais tarde, chegando a concordar parcialmente com a defesa de Bergson.

9 O recurso à filogênese serve a Freud como saída para a questão, posta em Totem e tabu, acerca da transposição do complexo de Édipo do indivíduo para a humanidade. Afinal, esse é de fato o objetivo último do livro: explicar psicanaliticamente a fundação da humanidade, a partir do mito parricida (MEZAN, 1986). Mas essa tese, que ora aparece de modo explícito em Totem e tabu, ora implícita e timidamente, em outros contextos da obra freudiana, náo é um ponto pacífico para o autor, porque lhe traz grandes complicaçôes teóricas concernentes à identificação do particular ao universal, as quais não nos caberão aqui analisar.
} 
obra. No entanto, a sistematização da teoria ocorreu de modo específico em 1915 e sua reformulação, em 1920. Primeiramente, no ensaio As pulsóes e seus destinos, Freud (1915/2013, p. 19) associa o estímulo pulsional à "[...] 'necessidade'; e para o que suspende essa necessidade, 'satisfação'. As pulsões denotariam, assim, o traço característico da vida interior, não podendo ser afastadas mecanicamente como um estímulo externo. A primeira teoria das pulsóes se vincula diretamente à compreensão do que Freud determinou como "princípio do prazer" (FREUD, 1915/2013, p. 23), ao qual estaria completamente sujeita a vida psíquica: um aumento de estímulo pulsional gera sensação de desprazer, ao passo que sua diminuição ou satisfação, prazer.

Apesar dos variados tipos e fontes de pulsóes, dois grupos delas seriam mais relevantes para uma melhor apreensáo da estrutura da vida profunda: "[...] as pulsóes do Eu, ou de autopreservação, e as pulsóes sexuais." (FREUD, $1915 / 2013$, p. 29, grifos do autor). Porém, no ano de 1920, no ensaio Além do princípio do prazer, essa primeira teoria de 1915 é reformulada. Nesse ponto, Freud reúne sob um mesmo título os instintos primitivos de autopreservaçáo e os sexuais, são as chamadas "pulsôes de vida”. Mas a grande novidade dessa segunda teoria são mesmo "as pulsóes de morte", as quais darão a tônica da metapsicologia freudiana em contextos variados. Podemos afirmar, em resumo, que a pulsão de vida nos impele a agir no sentido de conservar a vida, e a pulsão de morte, seu oposto, nos impede de agir, sendo, enfim, a busca pela ausência do estímulo. A pulsão de morte seria, portanto, uma tendência à estagnação e à repetição contra a qual se coloca a pulsão de vida.

Em Bergson (2005), uma tendência ao conformismo, ou à repetição, é implícita ao instinto social porque, como descreveu no primeiro capítulo d'As duas fontes, qualquer mudança na ordem social ou moral é vista como um risco ao grupo. Assim, também, a tendência evolutiva que conduz os organismos ao fechamento, visaria, em última instância, a preservar a vida. Por conseguinte, essa propensão humana a repetir hábitos e comportamentos sociais, ao contrário de um impulso negativo, oposto à vida, se colocaria à primeira vista, na obra de 1932, como um instinto de autopreservação. Porque, em certo sentido, para Bergson, toda vida que evolui busca se conservar, daí sua tendência natural ao fechamento. Em suma, a tendência que preserva a vida é sempre repetitiva, não gerando uma abertura para mudanças sociais, morais ou religiosas.

Porém, na filosofia bergsoniana, em sentido profundo, como energia espiritual, a vida é criação, mudança, transformação. Nessa medida, 
indagamos: não seria possível, então, associar a tendência ao estático em Bergson à pulsão de morte em Freud? Conforme a interpretação de Vincent Delacroix (2014), se considerarmos a existência de um paradoxo no vital, qual seja, que ao lado do impulso criativo há o assédio do estático, a imposição da materialidade inerte, poderíamos estabelecer certo paralelo entre a pulsão de morte freudiana e essa tendência à repetição e ao estático, descrita n'A duas fontes. Segundo Delacroix (2014), a repetitividade é o fundamento mesmo da religiosidade estática. Freud (1920/2014, p. 202) igualmente, por sua parte, associa o comportamento repetitivo a uma forma de ritualística religiosa, “[...] uma orgânica compulsão a repetir”, própria da chamada pulsão de morte. Dessa maneira, quando aborda a dualidade instintual primordial em constante disputa, a da vida contra a morte, Freud (1920/2014) parece permear o mesmo contexto reflexivo traçado por Bergson (2005).

Por outro lado, aponta coerentemente Arnaud François (2014), é preciso ter em mente certas divergências entre as ideias de morte e pulsão de morte em ambos os autores. Um retorno à obra de 1907, A evolução criadora, nos faria ver que, embora a resistência da matéria sobre o impulso vital seja marca de uma negatividade, porque barra o processo múltiplo e criativo do elã, no humano, a vida teria encontrado meios de superar-se. Certamente, partilhando da matéria e do espírito, a vida em geral não será capaz de "[...] deter a marcha das mudanças materiais" (2005a, p. 267) no caminho de sua própria degradação. Todavia, o autor d'A evolução criadora prefere ver também nesse processo um registro temporal criativo. Para ele, encarada em sentido amplo, a marcha do vivo para a morte poderia ser interpretada como parte do próprio ciclo vital, pois, “[...] no mundo organizado, a morte dos indivíduos não aparece de modo algum como uma diminuiçáo da 'vida em geral', ou como uma necessidade à qual esta se submeteria a contragosto." (BERGSON, 2005a, p. 268).

Com base nessa interpretação, François (2014) chama-nos atenção para o fato de que Bergson se recusa a admitir, em sua obra, pulsóes vitais tendentes à morte. Uma tendência à degradação é sempre atribuída pelo filósofo à matéria, não ao espírito; ao contrário de Freud, que reconhece incontestavelmente o predomínio dessas pulsões na esfera da vida. Ocorre que François (2014) constrói sua argumentação, amparando-se apenas n'A evolução criadora. O Bergson d'As duas fontes, muito provavelmente, impactado com as consequências de uma guerra e a iminência de outra, tratou a experiência da morte, ou a consciência dela, de modo bastante diferente. Aqui náo se 
fala mais da morte no contexto amplo de uma reflexão cosmológica, como a elaborada em 1907. Agora, é a perspectiva do sujeito, do indivíduo na sociedade, encarando seus próprios medos e angústias. Ou seja, se, do ponto de vista de um estudo da vida em geral, a morte é o caminho natural dos seres vivos, da perspectiva do eu, da duração psicológica, ela é algo incompreensível e assustador. É nesse ponto específico que a religiáo ganha espaço e sobre o qual a relação entre o que defende Bergson n'As duas fontes e a teoria das pulsóes de Freud fica mais evidente.

Uma suposição possível também nos salta aos olhos, na aproximação entre as ideias desses pensadores, a saber: quando Freud nos diz, em $O$ futuro de uma ilusão, que "[...] todo indivíduo é virtualmente um inimigo da cultura [...]" (1927/2014, p. 233-234), tema que aprofunda em $O$ mal estar na civilizaçâo (FREUD, 1930/2014), poderíamos também associar essa resistência do sujeito em relação ao que reprime seus impulsos primitivos a certa potência da inteligência para a desorganização, para o individualismo, enfim, para um ceticismo perigoso capaz de pôr em risco a vida e a organizaçáo social (BERGSON, 2005).

Se retomarmos agora nossa indagação inicial sobre a permanência de impulsos primitivos, os quais nos levariam a atos desmedidos e, aos olhos de nossa época, não civilizados, responderíamos, inspirados por Bergson e Freud: eles derivam desse "instinto" desagregador, o qual, ao lado da tendência à vida, nos impele também à morte. Mas tanto o eu individual quanto o eu social encontrarão meios adequados de resistência. $\mathrm{O}$ individual, através de uma repressão interna; o coletivo, entre a criação de outras instituiçóes, através da religião.

\section{Fabulação, Religiáo E MORAL NASCENTES}

Ao contrário dos outros animais, o ser humano é inseguro, teme o erro, teme a morte - e essas incertezas desestabilizam o equilíbrio natural. Nesse sentido, auxiliado por uma franja de instinto, resquício do processo evolutivo, o poder representativo da inteligência se insurge defensivamente em favor da vida. Criará, assim, uma função fabuladora. Embora essa função engendre toda sorte de criaçóes do imaginário humano, "[...] o romance, o drama, a mitologia [...]" (BERGSON, 2005, p. 100), ela é fundamentalmente de ordem religiosa. A fabulação configura, por isso, uma reação da natureza, um contrapeso, capaz de criar ficçôes úteis contra os perigos da ilimitada potência 
intelectual, a qual, elevada ao máximo poder de especulação, se confronta com sua própria finitude e com seus interesses individuais. A função fabuladora da inteligência cumprirá, portanto, um duplo papel: reequilibrar o apego à vida, ameaçado pelo poder deprimente do raciocínio, mas também o apego à sociedade, reintegrando os indivíduos desgarrados à vida coletiva. Tal função, sendo hábil em prover a representação de imagens reconfortantes, implicará a mais primitiva forma de religiosidade.

A religiáo dita estática tem seu fundamento tanto no social quanto na natureza, porque, além de devolver o apego à vida, ela "[...] tem por primeiro efeito sustentar e reforçar as exigências da sociedade.” (BERGSON, 2005, p. 26). A religiâo nascente será pródiga em reforçar nossa propensão à obediência, inibindo, dessa maneira, lampejos de individualismo que poderiam minar a ordem social. Isso é necessário, porque "[...] cada um de nós, quando se volta para si mesmo, se sente evidentemente livre de seguir seu gosto, o seu desejo e o seu capricho, e de não pensar nos outros homens." (BERGSON, 2005, p. 27). Ora, o ser inteligente tem o poder de superar-se criativamente. Sua capacidade inventiva está a serviço da vida e, por conseguinte, da organizaçáo social. Porém, ao contrário do animal irracional, que cumpre irrefletidamente sua função na sociedade instintiva, o animal humano pode refletir sobre sua própria condição e, livre de qualquer pressão, "[...] dotado de inteligência, desperto para a reflexão, virar-se-á para si próprio e não pensará senão em viver agradavelmente.” (BERGSON, 2005, p. 110).

Em Freud, uma tendência primitiva a "viver agradavelmente" também é vista como um perigo, quando a sociedade exige de seus membros certas renúncias em favor da civilização. Em 1911, o psicanalista publica o artigo Formulaçóes sobre os dois princípios do funcionamento psíquico, onde elabora os conceitos de princípio do prazer e princípio da realidade. Antes do aprofundamento da teoria das pulsóes, que mencionamos anteriormente, o autor compreendia esses princípios como regentes da vida psíquica. O aparelho psíquico funcionaria tal qual um mecanismo de fuga do desprazer, através do ganho de prazer (FREUD, 1911/2015). Um mecanismo útil na fuga do desprazer é o ato de fantasiar, pois, por seu meio, nós nos retiramos da realidade concreta, inserindo-nos em uma ilusão agradável. A fantasia “[...] tem início já na brincadeira das crianças e [...] depois, prosseguindo como devaneio, deixa de lado a sustentação em objetos reais" (FREUD, 1911/2015, p. 114-115, grifos do autor), o que se constata nos diversos casos de neurose estudados pela psicanálise. 
Mas a realidade se impóe, o "[...] eu-realidade necessita buscar o que é útil e proteger-se dos danos.” (FREUD, 1911/2015, p. 116). No caso específico da prática religiosa, é comum a renúncia aos prazeres mundanos. Entretanto, essa renúncia envolve a fantasia da salvaguarda do prazer como recompensa futura. Ou seja, nós nos submetemos às imposições morais que a religião e a sociedade nos ditam, com a esperança fantasiosa de obtermos no além todo o prazer que sublimamos em vida. Assim, ao substituirmos momentaneamente o prazer pela realidade, nós o fazemos em vista de "[...] um prazer seguro, que virá depois." (FREUD, 1911/2015, p. 117).

A fabulação religiosa em Bergson (2005) atua de forma semelhante. Ao criar condiçôes favoráveis para a religião nascente, a força de suas representaçôes, de seus "fantasmas de fatos", é tão potente quanto útil para conter o risco iminente da dissociação do vínculo social, da insubordinação à ordem e da descontinuidade da vida. Aqui é de uma religião natural que nos fala Bergson, infraintelectual, em estado nascente, quase um "instinto" de autopreservação, uma religião verdadeiramente estática, cuja base primordial se encontra na fabulação. Sua função primeira é preservar a vida, e a moral dela decorrente estará igualmente a serviço do vital, reforçando a organização social.

A religião naturalmente estática é solidária a uma moral social fechada, alheia à fraternidade universal. $\mathrm{Na}$ ausência da lei, está a cargo da religião forçar a solidariedade, a fim de garantir ou zelar pela sobrevivência do grupo. Nos grupos humanos rudimentares, então, a religião, ou o seu vislumbre, é toda a lei. Isso nos faz voltar a Freud, quando este elabora, entre 1912 e 1913, seu estudo sobre o totemismo, sistema primitivo de organização social e religiosa segundo o qual grupos de pessoas se dividem em clâs, cada um conforme o seu totem. No sistema totêmico, os membros de cada clã devem estar comprometidos com a observância dos tabus de não matar seu próprio totem e da exogamia. O estudo do totemismo, tanto para Freud quanto para Bergson, seria o ponto de partida para a compreensão da religiáo e, por conseguinte, da moralidade em estágio embrionário. ${ }^{10}$

\footnotetext{
${ }^{10}$ De acordo com Claude Lévi-Strauss (1975), em o Totemismo hoje, uma definição única do sistema totêmico será sempre ambígua, pois pesquisas sobre muitas culturas originárias teriam mostrado diversas discrepâncias, no que se entende por totem, clá e tabu. Por isso, o estudo do totemismo deveria antes se colocar como o estudo do "problema totêmico" (LÉVY-STRAUSS, 1975, p. 13-19). É preciso destacar, no entanto, a referência de Lévi-Strauss a Bergson, no quinto capítulo de seu livro. O antropólogo se surpreende com o fato de que o filósofo "[...] soube melhor que os etnólogos, ou antes deles, compreender certos aspectos do totemismo[...]", e ainda: “[...] parecerá certo admitir que Bergson pôde compreender o que se oculta por trás do totemismo porque seu próprio pensamento
} 
No prefácio à edição hebraica de Totem e tabu, Freud (1913/2015, p. 17) afirma que seu livro "[...] aborda a origem da religiáo e da moralidade." Esse é também o tema d'As duas fontes. E, além da identificação temática, as obras também se aproximam teoricamente. Notamos que, em Totem e tabu (1913/2015), através do estudo do comportamento de povos aborígenes australianos, Freud conclui, igualmente a Bergson (2005), que certos padróes de moralidade estão presentes desde o início das associações humanas, muito antes de estabelecidos outros modelos de existência, como o cultivo do solo ou a criação de animais, por exemplo. Preceitos morais sempre estiveram profundamente ligados aos costumes totêmicos, concretizando-se por meio da instituição de tabus, cuja função pragmática é fundamental à vida social. Dos tabus derivaram superstiçóes e, consequentemente, a crença em espíritos, deuses e demônios, enfim, a religião tal como a conhecemos.

A fim de explicar a origem histórica, psíquica e social da religião, Freud (1913/2015, p. 216) cria o mito da horda primeva. O mito freudiano conta que, quando um grupo de irmáos se rebela contra a autoridade do pai “[...] violento e ciumento, que reserva todas as fêmeas para si $[. .$.$] ”, tem início o$ sistema totêmico:

Certo dia, os irmãos expulsos se juntaram, abateram e devoraram o pai, assim terminando com a horda primeva. Unidos, ousaram fazer o que não seria possível individualmente (Talvez um avanço cultural, o manejo de uma nova arma, tenha lhes dado um sentimento de superioridade.) $\mathrm{O}$ fato de haverem também devorado o morto náo surpreende, tratando-se de canibais. Sem dúvida, o violento pai primevo era o modelo temido e invejado de cada um dos irmáos. No ato de devorá-lo eles realizavam a identificação com ele, e cada um apropriava-se de parte da sua força. A refeição totêmica, talvez a primeira festa da humanidade, seria a repetiçáo e a celebração desse ato memorável e criminoso, com o qual teve início tanta coisa: as organizaçóes sociais, as restriçóes morais, a religiâo. (FREUD, 1913/2015, p. 216-217).

Para Freud, derivam desse parricídio o sentimento de culpa e o medo, os quais originarão a religião e a moral refletidas no totemismo, através dos tabus basilares da civilização. Os sentimentos ambivalentes em relação ao pai (complexo de Édipo) deram lugar ao arrependimento por seu assassinato, o que atribuiu ao morto um poder maior sobre os vivos. Os filhos parricidas

estava, sem que ele o soubesse, em sintonia com o de povos totêmicos." (LÉVY-STRAUSS, 1975, p. 102). Sobre essa relação apontada por Lévi-Strauss entre a filosofia de Bergson e o pensamento de povos indígenas, vale conferir o artigo de André Robinet, "Bergson et l'indien Sioux" (1991). 
“[...] revogaram seu ato, declarando ser proibido o assassínio do substituto do pai, o totem, e renunciaram a consequência dele, privando-se das mulheres então liberadas." (FREUD, 1913/2015, p. 219). Em decorrência do assassínio do pai, os dois grandes tabus do totemismo se fundaram: as proibiçóes do assassinato e do incesto. O primeiro teria valor afetivo, enquanto o segundo, valor prático: a rivalidade entre irmáos na disputa pelas mulheres se tornaria um fator de divisão, de sorte que, a fim de manter-se a coesão do grupo social, seria necessário renunciar às relaçóes sexuais entre membros do mesmo totem.

O estudo do tabu como fruto da religiosidade nascente, pré-reflexiva, conformada à capacidade humana de fabular o real, revela a Bergson (2005) e, em certa medida, também a Freud, que, de um ponto de vista pragmático, seu caráter racional se sobrepóe à fabulação, quando concebemos, por exemplo, o interesse social e vital da proibição sexual entre parentes. E, não obstante a vida civilizada tenha renunciado, até certo ponto, a muitas interdiçóes consideradas primitivas, formas lapidadas de tabu subsistem entre nós. Remontam ao tabu, por exemplo, as formas mais primitivas de punição e, por se tratar de um mecanismo de regulação das açôes do indivíduo no totem a que pertence, é do tabu que se origina também a consciência moral. Assim, a religiosidade manifestada em interditos morais tem, para Bergson (2005, p. 236), uma função nitidamente demarcada, qual seja, a da conservação social, porque é no fundo uma "segurança contra a desorganização".

\section{A RELIGIĀo CONTRA A MORTE E O IMPREVISÍVEL}

Vimos que a religião é uma ferramenta útil, quando a representação intelectual ameaça o equilíbrio da vida. A consciência da morte talvez seja a principal fonte de desequilíbrio vital, no mundo natural. Afinal, como frisa Bergson (2005, p. 117), ressoando, a seu modo, a dualidade freudiana entre pulsão de vida e pulsão de morte, "[...] se o impulso de vida afasta todos os outros seres vivos da representação da morte, o pensamento da morte deve abrandar no homem o movimento da vida." Enfim, “[...] a certeza de morrer, surgindo com a reflexão num mundo de seres vivos feito para pensar apenas em viver, contraria a intenção da natureza."

$\mathrm{Na}$ tentativa de lidar com a finitude, a religião apresenta uma solução útil: ela promete a vida além vida. A crença na imortalidade da alma se tornará, portanto, outro expediente necessário à colaboração social. $\mathrm{O}$ animismo, ou "doutrina das almas" (FREUD, 1913/2015, p. 121), será notado em 
praticamente todas as culturas primitivas. A representação originária da alma como "[...] um corpo que sobrevive a si mesmo" (BERGSON, 2005, p. 119) é catalogada pela ciência das religiôes com diversos termos: mana (polinésio), wakanda (sioux), orenda (iroqueses), pantang (malaios) (BERGSON, 2005). Mas o animismo, segundo Freud, ainda não é uma religião propriamente dita; seria antes uma visão de mundo, um sistema de pensamento donde tiveram nascimento o mito e a religiáo. Pouco a pouco, a crença na imortalidade da alma dá lugar ao culto dos antepassados, os quais doravante adquirirão um caráter quase sagrado. Eles serão a sustentação da sociedade rudimentar. na ausência das instituiçóes (FREUD, 1913/2015).

Essa visão fabulosa de mundo, necessária no contexto das sociedades primevas, permanece útil no contexto das civilizadas, porque a religião instituída manteve inalteradas, por exemplo, as concepçóes de alma, do divino, do sagrado, assim como muitos tabus ancestrais. E, conforme as exigências da manutenção da vida coletiva se imponham, "[...] não há absurdo em que a inteligência náo possa cair.” (BERGSON, 2005, p. 121). É de fato impressionante o ponto a que pode chegar a fantasia humana, ao tentar fugir de seus próprios demônios, isto é, das questôes que jamais responderá racionalmente e das consequências psíquicas e sociais que essa falta de respostas desencadeia. Ora, assim como são naturais as questôes existenciais para as quais não temos respostas, a fabulação defensiva também o é. A fabulação pode ser um consolo para o medo da morte, porém, pode também ser fonte de muitas neuroses. Não à toa, Freud entenderá a religião como uma espécie de "[...] neurose obsessiva universal da humanidade" (FREUD, 1927/2014, p. 284). E essa definição do fenômeno religioso, embora mais feroz, em muito se aproxima do que Bergson (2005) define como religiáo estática.

Além do medo da morte, há também o medo do que não se pode prever. $\mathrm{O}$ fato de que, em nossa cultura, a ciência consiga atingir graus elevados de previsibilidade não aplaca nossa angústia frente à indeterminação do porvir. Para além das respostas científicas, a necessidade de controle nos levou às mais diversas fabulaçóes de que se tem notícia. Pela fabulação, aprendemos a preservar o convívio social, a partir da pressão dos costumes assentados e dos tabus inquestionáveis. Aprendemos também a não temer a morte, porque depois dela permaneceremos. Com efeito, diante das imprevisíveis ocorrências da duração, às quais estamos permanentemente expostos, a religião encontrará um sentido a mais no plano cultural. Quando a inteligência parece querer nos fazer encarar a realidade de uma forma pessimista, ou talvez mais realista, 
acende-se em nós novamente a fabulação. Ela traz consigo uma carga de otimismo condensado em superstiçóes e pensamentos mágicos capazes de nos guiar em direção ao desconhecido, tornando-nos confiantes, quando a razão alerta para o perigo.

Embora a crença em potências mágicas que viriam ao nosso auxílio em situaçóes incontroláveis e imprevisíveis creia-se ultrapassada, em indivíduos racionalmente cultivados, não nos surpreenderá se encontrarmos entre nós mesmos, seres de ciência, as mais "primitivas" superstições. Certamente, o curioso campo das crenças supersticiosas é bem explorado pela psicologia em geral. Contudo, o próprio Bergson, suspeitando de atividades inconscientes do espírito, ressalta: "Ora, quer se trate de selvagens ou de civilizados, se quisermos saber o fundo do que um homem pensa, devemos reportarmonos ao que faz e não ao que diz." (BERGSON, 2005, p. 126). Primitivo ou civilizado, haverá momentos em que o ser humano se deixará levar por uma espécie de "preguiça” para a reflexão (BERGSON, 2005, p. 133), a qual abrirá inevitavelmente caminho para a fabulação.

A preguiça de pensar implica diretamente uma divinização do mundo, cujo objetivo é abrandar a representação deprimente a que a inteligência nos expóe. Assim, a crença em entidades fantásticas tem sua origem, primeiramente, numa espécie de "garantia contra o medo" (BERGSON, 2005, p. 134). Esse medo pode se referir às incertezas do futuro, mas também às do presente, como a ocorrência de um fenômeno mortal, como a erupção de um vulcão, um maremoto, uma tempestade ou até mesmo uma pandemia. A resposta da religião estática se concretiza no animismo e evolui para a antropomorfização do mundo natural. Se não podemos controlar empiricamente os fenômenos, atribuímos a eles características psicológicas. Nesse sentido, a religião nascente poderá também ser descrita como "[...] menos o medo que uma reação contra o medo [...]” (BERGSON, 2005, p. 134).

Uma situação ilustrativa do que aqui tratamos é extraída por Bergson (2005) de um relato do filósofo William James, quando este sentira pela primeira vez o efeito de um tremor de terra. James revela sua percepção espontânea do ocorrido como a de alguém que, a despeito de toda cultura científica e filosófica, personifica o episódio imprevisto. $\mathrm{O}$ tremor era para ele um sujeito, um ser que se insinuava ao indivíduo William, a fim de destruí-lo: "Vejo agora como eram inevitáveis as antigas interpretaçóes mitológicas das catástrofes desse gênero, e como são artificiais, como contrariam a nossa percepção espontânea, os hábitos posteriores que a 
ciência através da educação imprime em nós." (JAMES, 1911, p. 209-214 apud BERGSON, 2005, p. 136).

Em seu ímpeto espontâneo, James humanizou o tremor, tornando o fenômeno familiar: "O abalo era 'perverso'; 'tinha metido na cabeça destruir'.É assim que se fala de um mau rapaz, com o qual nem por isso se teráo quebrado necessariamente todas as relaçôes." (BERGSON, 2005, p. 137). Aproximar-se do fenômeno foi uma forma de vencer o medo, o que demonstra mais uma vez o papel da fabulação como mecanismo natural de defesa. Em momentos excepcionais, sobretudo em situaçóes de perigo iminente, seria então possível notar como a inteligência cultivada cede facilmente lugar à fantasia, em busca de proteçấo, como somos enfim psicologicamente "primitivos".

Ao lado da superstição e da antropomorfização do real está a magia, que se realiza igualmente em uma zona pré-reflexiva, onde a franja de instinto é mais atuante que a inteligência. A crença na magia se caracteriza pela clara ideia de que a matéria possui "[...] a faculdade de cumprir desejos e obedecer ordens" (BERGSON, 2005, p. 145). Logo, o mundo natural seria condescendente aos desejos humanos. A atuaçáo preponderante do desejo no pensamento mágico também é explicada e exemplificada por Freud, ao longo da terceira parte de Totem e tabu, intitulada "Animismo, magia e onipotência dos pensamentos". Ali, o psicanalista (1913/2015, p. 126) assinala: “[...] a magia tem de servir aos propósitos mais diversos: submeter os eventos naturais à vontade do homem, defender a pessoa dos perigos e dos inimigos e dar-lhe o poder de prejudicar seus inimigos."

Todavia, assim como o pensamento mágico é próprio dos humanos, sendo exercido, na visão bergsoniana, por uma espécie de pressão do instinto sobre a inteligência, também nos é inerente a tendência ao conhecimento científico, a recusa da magia, da superstição e da ilusão. Bergson (2005) discorda entáo da ideia de que a ciência seja um prolongamento da magia, pois, ainda que persigam igualmente a compreensão do mundo, em termos de previsibilidade e controle, magia e ciência são, para ele, produtos de tendências opostas no ser humano, mas que se confundem por sua constituição mista. As sociedades que permaneceram não civilizadas teriam sido aquelas que escolheram o entorpecimento cômodo do pensamento mágico, escolheram, enfim, a "preguiça” para a reflexão. 


\section{A CRENÇA EM DEUSES E A RELIGIĀo DINÂMICA}

Se os avanços da ciência findaram por minar pouco a pouco a visão animista e mágica do mundo, "[...] permanece o desamparo do ser humano, e, com isso, o anseio pelo pai, e os deuses." (FREUD, 1927/2014, p. 249250). Ora, de uma compreensão mais disseminada das potências místicas do mundo natural, chega-se à ideia de deuses antropomorfizados, um produto tardio da fabulação porque não decorre diretamente da religião natural, estritamente estática, a qual brota da fabulação como resistência à inteligência (BERGSON, 2005). Parece que a crença em deuses já é algo pensado, em certo sentido, fruto de reflexão. $\mathrm{O}$ mito, que é a personificação de potências divinas, floresce justamente nas sociedades antigas já civilizadas ou na via da civilização, constituindo-se como base de sua política, economia, religião e educação.

O deus é um sujeito, uma personalidade, diferentemente do espírito, que seria mais uma força, uma presença, um ato (BERGSON, 2005). A riqueza dos mitos gregos, egípcios, chineses, hindus etc. mostra como a fabulação, correndo livre, pôde criar as mais variadas e complexas representaçôes, e o poder dessa faculdade de interferir no modo de vida pessoal e social dos grupos humanos foi igualmente capaz de criar as condiçôes para a produção da arte, ciência e filosofia de que temos conhecimento. Tudo isso garante que, embora a experiência religiosa possa ocorrer individualmente, é na sociedade que ela se realiza, de maneira eficaz. E a religiáo talvez seja a ferramenta mais potente de coesão social, visto que "[...] reforça a disciplina" (BERGSON, 2005, p. 171), através de rituais, preces, sacrifícios e mandamentos.

Essa já não é, no entanto, a religião verdadeiramente estática. Volta e meia a religiosidade natural ressurge em situaçóes-limite, mesmo em espíritos intelectualmente cultivados. Como o caso mencionado por W. James e retomado por Bergson, ou o caso do autodeclarado amigo de Freud (1930/2014, p. 14-16), cuja experiência de um "sentimento oceânico", suposta fonte originária da religiosidade, é relatada em $O$ mal-estar na civilização. A religiáo verdadeiramente estática é naturalmente fruto de uma experiência infraintelectual, quase instintiva, destinada "[...] a afastar perigos que a inteligência poderia fazer o homem correr.” (BERGSON, 2005, p. 160). É bom lembrar, de uma perspectiva epistemológica, que o termo "estático" em Bergson remete à superficialidade, a um conhecimento mediado pelo espaço, cuja característica principal consistiria na distinção entre aquele que conhece e o objeto conhecido. 
Logo, ainda que a religiâo estática, como produto da função fabuladora, venha ao auxílio da sociedade. quando mantém a coesão do grupo, o equilíbrio social e, de algum modo, vital, só se realizará ao custo de que cada um de nós precise renunciar à sua originalidade profunda, a seus desejos mais íntimos, tudo em nome da segurança na vida coletiva. Eis o paradoxo da religião estática: seu objetivo é preservar a vida em geral, mas a vida que se individualiza em duração psicológica, a vida profunda de cada ser humano, é algo que apenas outra forma de religiosidade poderia tocar, uma religião dinâmica, fruto de uma experiência "supraintelectual", uma experiência mística por excelência.

A religião dinâmica nasce de um misto entre o infra e o supraintelectual (BERGSON, 2005). A mística propriamente dita ultrapassa o que se entende comumente por religião, e o que temos descrito até então como fruto do domínio infraintelectual. A verdadeira mística, por conseguinte, restringese à experiência intuitiva de indivíduos excepcionais, cuja moral se abre à humanidade. Nesse sentido, ela nem poderia de fato se caracterizar como religião, mas como um "certo modo de existência humana" (GOUHIER, 1999 , p. 117) superior ao comum. Tal modo de existência é o da abertura moral e se concretiza na figura do místico. Contudo, o próprio Bergson (2005, p. 182) o diz: "[...] o misticismo puro é uma essência rara."

Em suma, a "religião dinâmica" seria fruto da experiência mística, mas sua prática e instituição não são propriamente místicas. Todo o desenvolvimento da religião em doutrinas dogmáticas condensaria, dessa maneira, o misto entre estático e dinâmico. Assim, a conversão da religiosidade primitiva em religiôes instituídas passaria também pela experiência de sujeitos excepcionais, os quais teriam extrapolado as "intençóes" do elã vital para a espécie e influenciado, com seu exemplo, outros indivíduos, sociedades e naçôes. De sua experiência intuitiva com o impulso de vida que alguns denominam Deus, teriam, através de sua ação no mundo, irradiado essa potência de transformação da solidariedade social em fraternidade humana.

\section{ILusấo vs Mística}

Ao contrário do filósofo francês, porém, Freud não enxergou para a religião qualquer futuro glorioso. Para ele, haveria apenas isso que Bergson entendeu como religião estática, fruto da fabulação, do medo, do desejo. Freud realmente não viu possibilidade de abertura moral através da religiosidade. Sendo as doutrinas religiosas indemonstráveis, segundo ele, elas não passam de 
ilusôes do “[...] inventário psíquico de uma cultura." (FREUD, 1927/2014, p. 245). Tal qual a arte e outros meios entorpecentes, ainda que ideias religiosas funcionem como "satisfaçôes substitutivas" para as renúncias culturais, renúncias se transformam em mal-estar, em neuroses com as quais a própria civilização precisa lidar, se quiser evoluir (FREUD, 1930/2014).

Ilusão, de uma perspectiva psicológica, é justamente a crença cuja motivação é proveniente de um desejo. $\mathrm{O}$ inconformismo com a condição humana, com sua impotência, sua pequenez, gera a crença em tais fabulaçóes. Precisamos crer que somos o centro e a razáo de ser do universo; do contrário, nós nos sentiríamos completamente abandonados, desamparados, como qualquer outra criatura viva. Quem crê nessa primazia do humano é religioso. Por outro lado, dirá Freud (1927/2014, p. 270), “[...] quem não vai adiante, quem humildemente se conforma com o mínimo papel do ser humano neste mundo imenso, este é, na verdade, irreligioso no autêntico sentido da palavra."

Nessa visão psicanalítica, a compreensão religiosa da realidade serve de alento ao peso de uma existência abandonada que espera a criança desde o seu nascimento. A proteção paterna obtida na infância, e perdida na vida adulta, será substituída pela proteção divina, pela ideia de um deus que, antes de tudo, é o pai. Portanto, a força das doutrinas religiosas sobre o poder da racionalidade deriva diretamente de um desejo profundo de proteção. A religião torna-se, assim, o agradável consolo na vida adulta para angústias nutridas desde a infância. Mas não passa de uma ilusão derivada de um desejo e "[...] nesse aspecto ela se aproxima do delírio psiquiátrico." (FREUD, 1927/2014, p. 267).

Está claro que a ideia freudiana de ilusão, decorrente do desejo de controle, do medo da morte e do desamparo paterno, caminha lado a lado com a noção de fabulação, em Bergson. Conforme ambos os pensadores, a religiáo se insurge como meio de amenizar o fardo da vida social, das regras impostas, a frustração oriunda das renúncias instintuais exigidas pela civilização. Os autores também concordam que, apesar do consolo quase narcótico que a religiáo trouxe aos anseios humanos, ao longo da história, ela náo contribuiu o bastante "[...] para domar os instintos associais [...]" (FREUD, 1927/2014, p. 276), pois a civilização está repleta de indivíduos infelizes, hostis à cultura e à moralidade, incapazes de jogar o jogo social.

Além disso, por seu caráter dogmático sustentado pela fabulação, a crença religiosa instituída no seio de uma sociedade fechada, muitas vezes, dá 
lugar à intolerância, a preconceitos os mais diversos, a atitudes cruéis e imorais (BERGSON, 2005). A repressão de comportamentos ditos excêntricos será consequência direta dessa intolerância, o que se efetiva de diversas maneiras: da supressão da dignidade social, da ridicularização, enfim, de métodos brandos de punição, até as mais cruéis formas de cerceamento e descarte. E a intolerância se reforça, quando se torna um pensamento coletivo. Daí que a religiosidade compartilhada seja seu ambiente propício.

Por esses e outros motivos, na visão freudiana, a religião é uma etapa a ser superada pela humanidade, em vista de seu amadurecimento cultural. Ela estaria para a civilização tal qual a infância está para o ser humano. Ocorre que, no lugar dessa religião, Freud confere toda autoridade à ciência. Eis aqui expressa sua descrença:

Não há instância acima da razão. Se a verdade das doutrinas religiosas depender de uma vivência interior que ateste essa verdade, o que fazer das muitas pessoas que não tem essa rara vivência? Pode-se requerer que todas as pessoas utilizem o dom da razão que possuem, mas náo se pode estabelecer uma obrigação válida para todos com base num motivo que existe apenas para uns poucos. Se um indivíduo obtém a convicção inabalável da verdade das doutrinas religiosas após ser tomado de profundo êxtase, que significado tem isso para os outros? (FREUD, 1927/2014, p. 264).

Supomos que uma resposta bergsoniana para essas perguntas retóricas de Freud passaria pela compreensão metafísica do místico como um ser, o qual, por seu contato imediato com o elã da vida, e através da sua ação no mundo, poderia contagiar outros indivíduos a seguirem seu exemplo. Mas, como frisamos, ao contrário de Bergson, Freud não vê saída para o progresso cultural da humanidade senão na ciência. A religião, seja ela instituída ou a "ilusão" de uma experiência mística, não contribui em nada para o amadurecimento psíquico da espécie, porque "[...] seria uma vantagem indiscutível deixar Deus de fora e honestamente reconhecer a origem puramente humana de todas as instituiçôes e normas culturais." (FREUD, 1927/2014, p. 281).

Assim como toda criança, que, em seu desenvolvimento psíquico, deverá superar espontaneamente a fase de neurose oriunda de seus medos infantis, também a humanidade deverá, aos olhos de Freud, superar sua fase neurótica concretizada na crença religiosa; deverá, por fim, abandonar suas ilusóes. Embora o poder da religiấo seja tal que se compare a "[...] um estado 
de alegre confusão alucinatória” (FREUD, 1927/2014, p. 285), sua superação será passo fundamental para o processo de crescimento civilizatório. Tal fase o psicanalista julgou estar em curso em sua época (FREUD, 1927/2014). Julgamento, no entanto, equivocado, como a história logo pôde e continua a atestar.

\section{ConsideraÇốES FinaIS}

Voltando-nos agora para as questôes iniciais, já podemos afirmar: as religióes não contradizem a inteligência, uma vez que sejam, de algum modo, produto dela. Considerando-se que a função fabuladora é fruto da inteligência, mas também de um resquício de instinto que visa à prevenção da vida, a religião, em seu estado mais rudimentar, ao fim e ao cabo, não deixa de ser também criação do intelecto. Daí não se possa dizer que povos "primitivos" sejam menos evoluídos, intelectualmente, por forjarem um mundo regido por fábulas. Os civilizados também o fazem, só que por outros meios.

Transpondo essa análise para o tempo presente, a fim de compreendermos nossa própria sociedade, as ideias de Bergson e Freud, surpreendentemente, continuam pertinentes. Um lance de olhos para a situação atual da sociedade brasileira parece trazer à tona uma realidade um tanto distópica, mas, ainda assim, real. Grande parte da população do nosso país sucumbiu à fabulação mais rústica possível. Despropósitos terraplanistas, anticientíficos e negacionistas proliferam desenfreadamente, entre círculos sociais considerados civilizados. Isso tudo só reforça, a nosso ver, a ideia freudiana da religião como neurose coletiva, porque, no fundo da realidade social e política brasileira atual, há uma religiosidade patente, a qual pode ser falsa, estratégica, é claro, mas muito conveniente em uma sociedade cada vez mais fundamentalista.

Foi por termos perseguido a via do fechamento que toda sorte de preconceitos e catástrofes tiveram lugar e, ao que parece, vem se intensificando em nossa história recente. Obviamente, algumas sociedades se modificaram, na tendência de uma maior racionalização, com o avanço da ciência e da técnica. Mas outras radicalizaram a tendência à fabulação. Nestas, a lógica do absurdo encaminha os indivíduos cada vez mais longe em seus delírios, alguma coisa comum entre grupos que se fecham em si mesmos, desprezando o que vem da exterioridade. Em 1932, ao descrever o funcionamento de nossa estrutura psicossocial, Bergson não pôde prever esse futuro insólito. No contexto de suas ideias, a fabulação era uma ferramenta útil à sociedade fechada, porque 
capaz de manter a coesão de seus elementos principais, os indivíduos, todavia, em nenhuma hipótese. deveria comprometer o progresso do conhecimento.

A "intençáo" da natureza teria sido apenas a de proteger a vida, preservá-la. Por isso, "[...] a inteligência, ao acabar de formar-se, fora invadida pela superstição.” (BERGSON, 2005, p. 100). Mas agora, em plena pandemia de um novo coronavírus que, neste momento em que escrevo, já ceifou mais de 70.000 vidas, o que vemos em nosso próprio país nem Bergson nem Freud poderiam prevê-lo: a fabulação está contra a vida em geral. Seu uso é deliberado, apropriado a favor de interesses escusos. Fabulando, alegam não passar de um resfriado uma doença mortal, alegam também ser possível tratá-la com placebo e oração; reivindicam, enfim, a fantasia no lugar do conhecimento, e as ilusôes só se multiplicam.

A grande questão não é mais aquela posta por Bergson, em 1932 - a de saber como a religião, além de ter sobrevivido, se expandiu enormemente, resistindo aos arroubos da razão. Se a religião nasceu do perigo contido na falta de sentido da vida, no mistério que ela comporta e em nossa incapacidade de solucioná-lo, e ela tem resistido bravamente frente ao avanço cada vez mais notável da ciência e da técnica, perguntamos agora: para onde vai a religião, ferramenta natural de preservação da vida, quando a ciência e a técnica já não são seus maiores adversários, mas a própria fabulação que tanto lhe servira na preservação da espécie?

MONTEIRO, G. P. Religion, life and society: brief study from Bergson and Freud. Trans/form/ação, Marília, v. 44, n. 3, p. 151-176, Jul./Set., 2021.

\begin{abstract}
The article aims to inquire to what extent religiosity, observed from its original context, would be away found by civilization to stifle primary human impulses tending to social and moral breakdown. In spite of this attempt at control, we question how much these so-called primitive impulses prevail in our biological, psychological and social constitution in order to justify aberrant behaviors so common in our time. We will start from the Henri Bergson's ideas, presented in the second chapter of The two sources of moral and religion, entitled "The static religion" in comparison with Sigmund Freud's arguments presented, above all, in The future of an illusion and Totem and taboo. Although the proximity with the social sciences, we will follow the hypothesis that Bergson's book carries out a more fruitful dialogue with Freudian theory regarding the understanding of the socalled primitive religiosity in opposition, or not, to the civilized one.
\end{abstract}

Keywords: Bergson. Freud. Religion. Moral. Life. Society. 


\section{REFERÊNCIAS}

BERGSON, H. A evoluçáo criadora [1907]. São Paulo: Martins Fontes, 2005a.

BERGSON, H. As duas fontes da moral e da religiáo [1932]. Coimbra: Almedina, 2005.

CAEYMAEX, F. À propos de l'émotion creatrice. Vie, instituition et histoire dans Les deux sources. In: FRANÇOIS, A.; RIQUIER, C. Annalles bergsoniennes VIII: Bergson, la morale, les émotions. Paris: PUF, 2017.

DELECROIX, V. La religion comme répétition. Bergson à la lumière de Freud. In:

SITBON, B. Bergson et Freud. Paris: PUF, 2014. p. 99-119.

DELITZ, H. L'impact de Bergson sur la sociologie et ethnologie françaises. Revue l'anée sociologique, Paris, v. 62, n. 1, p. 41-65, 2012.

FRANÇOIS, A. La division de la vie. Création, conservation et pulsion de mort chez Bergson et Freud. In: SITBON, B. Bergson et Freud. Paris: PUF, 2014. p. 121-139.

FREUD, S. Formulaçóes sobre os dois princípios do funcionamento psíquico [1911]. In: FREUD, S. Obras completas, v. 10. São Paulo: Companhia das Letras, 2015.

FREUD, S. Totem e tabu [1913]. In: FREUD, S. Obras completas, v. 11. São Paulo: Companhia das Letras, 2015.

FREUD, S. Introdução ao narcisismo [1914]. In: FREUD, S. Obras completas, v. 12. São Paulo: Companhia das Letras, 2015.

FREUD, S. As pulsóes e seus destinos [1915]. Belo Horizonte: Autêntica, 2013 (Obras incompletas de Sigmund Freud).

FREUD, S. O futuro de uma ilusão [1927]. In: FREUD, S. Obras completas, v. 17. São Paulo: Companhia das Letras, 2014.

FREUD, S. O mal-estar na civilização [1930]. In: FREUD, S. Obras completas, v. 18. São Paulo: Companhia das Letras, 2014.

GOUHIER, H. Bergson et le Christ des Évangiles. Paris: Vrin, 1999.

LÉVY-STRAUSS, C. O totemismo hoje. Petrópolis: Vozes, 1975.

MEZAN, R. Freud pensador da cultura. São Paulo: Brasiliense, 1986.

PINTO, D. M. A análise bergsoniana do social entre natureza e cultura: psicologia, biologia e filosofia moral à luz da duração. Dissertatio, v. supl. 4, dez. 2016.

ROBINET, A. Bergson et l'indien Sioux. Revue Internationale de Philosophie, v. 2, n. 177, p. 97-107, 1991.

SITBON-PEILLON. B. Religion, méthaphysique et sociologie chez Bergson: une expérience integrale. Paris: PUF, 2009. 
MONTEIRO, G. P.

WINOGRAD, M. Freud e a filogenia anímica. Revista do Departamento de Psicologia - UFF, v. 19, n. 1, p. 69-82, jan./jun. 2007.

WORMS, F. Le vocabulaire Bergson. Paris: Ellipses, 2000.

WORMS, F. Bergson ou les deux sens de la vie. Paris: Quadrige/PUF, 2004.

Recebido: 13/7/2020

Aceito: 11/9/2020 